\title{
Disruption in global supply chain and socio-economic shocks: a lesson from COVID-19 for sustainable production and consumption
}

\author{
Zhang Yu ${ }^{1} \cdot$ Asif Razzaq $^{2} \cdot$ Abdul Rehman $^{3} \cdot$ Adeel Shah $^{4} \cdot$ Kiran Jameel $^{5} \cdot$ Rahul S Mor $^{6}$
}

Received: 19 August 2020 / Revised: 16 November 2020 / Accepted: 14 January 2021 / Published online: 18 March 2021

(C) The Author(s), under exclusive licence to Springer Science+Business Media, LLC part of Springer Nature 2021

\begin{abstract}
The novel COVID-19 has emerged as a severe threat to global health globally, affecting over 210 countries and regions. The profound dilemma interrupted global trade and social activities and enormously influenced daily lives through social distance and confinements. The outbreak of COVID-19 has exacerbated human misery due to the crippling of economies globally. The effects are substantial on health, economy, environment, and society. Nearly every country is trying to prevent the transmission of this communicable disease. Remedial policies include testing and treating patients, isolating suspects through contact tracking, banning public gatherings, and asserting a complete or partial shutdown. In this context, the present paper's core objective is to investigate the impact of the COVID-19 pandemic on the environment and energy market, society, economy, and global protective measures taken to reduce COVID-19 transmission. The study's main contribution is revealed lessons to provide insights for business and the efficacy of governments' initiative globally. Finally, this paper describes future actions for governments, leaders, energy providers, and all stakeholders in response to the global pandemic crisis.
\end{abstract}

Keywords COVID-19 - Sustainable production · Sustainable practices · Environmental policies $\cdot$ Renewable energy · Sustainable consumption

\section{Introduction}

One hundred years ago, history's worst influenza pandemic (Spanish flue 1917-18) devastated communities and left millions of survivors, friends, and family to bear the heavy losses. Since then, human civilization has encountered several pandemics that mainly include; H1N2 Asian flu in 1957-1958, HIV/AIDS in 1981, SARS in 2003-2004, H1N1 in 2009-2010, Ebola in 2014-2016, Zika virus 20152016, and Ebola again in 2019. Recently, the world has encountered another epidemic disseminated as COVID-19 originated in Wuhan, China (Zhu et al. 2020; Huang et al. 2020) and spread worldwide that induce World Health Organization (WHO 2020) to declare it as pandemic on March 11, 2020. By definition, a pandemic is a worst-case scenario when an epidemic spread beyond a country's borders. These epidemics globally impinged the number of mortalities, health risks and cost billions of dollars (Khan et al. 2020a; Awan et al. 2020; Allocati et al. 2016; Fan et al. 2019). These pandemics increase concerns regarding public

1 School of Economics and Management, Chang'an University, Xi'an, China

2 School of Management and Economics, Dalian University of Technology, Dalian, China

3 Asia-Pacific Science Center Pte. Ltd, Centro Bianco 534818, Singapore

4 Institute of Business Management (IOBM), Karachi, Pakistan

5 Hamdard Institute of Management Science, Hamdard University, Karachi, Pakistan

6 Department of Food Engineering, National Institute of Food Technology Entrepreneurship and Management, Sonepat, India 
health and instigate ruinous socio-economic crises in the disease-ridden regions.

Amid rising socio-economic shocks of COVID-19 across the globe, about 40-60 million people fall into extreme poverty due to the informal sector's highest unemployment rate. Social insurance companies secure a few percentages of affectees. However, a major portion of about $55 \%$ of the world's population (as many as four billion people) is not covered by social insurance or social assistance. Besides, millions of people are trapped in the vulnerable category, prone to fall in poor with nominal economic shock. On the other hand, about $70 \%$ of COVID-19 quarantining women faced domestic violence that distorts their social status. These damages jeopardize our education system as nearly 1.2 (68\% of total) a billion students are out of school. Furthermore, 1/3 of the world's IDPs live in 10 countries most at risk, about 1.6 billion informal workers lost $60 \%$ of their income, remittances are expected to fall by almost $20 \%$, cutting off a significant lifeline to many vulnerable households, 27\% decline in global trade, about 265 million people in low and middle-income countries at risk of acute food insecurity, about 850 million to 1.1 billion loss of international tourists and about 100 to 120 million jobs of tourism-based industries (UNDP 2020).

The outbreak has hysterically spread out to 210 countries worldwide and exceeds 19,804,420 confirmed infected cases, while 729,591 testified deaths as of 9th Aug 2020 (Worldometer 2020). In order to 'flatten the curve' (Avi
2020), governments have imposed travel restrictions, border shutdowns, business discontinuity, and quarantine (GOV UK 2020; CPN 2020) in countries which comprise the world's largest economies, sparking uncertainties of an imminent recession and economic crisis (Buck et al. 2020). Despite these efforts, some countries are still shown persistent growth in confirmed cases and deaths (Bai et al. 2020; Awan et al. 2018; Lai et al. 2020). This unforeseen fallout appears due to the inaccessibility of the diseaseresistant vaccine and drug. Nonetheless, the top ten most affected countries, United States, Brazil, India, Russia, South Africa, Peru, Colombia, Chile, Spain, are worsening as $5,149,723$ confirmed cases and 165,070 deaths $8^{\text {th }}$ Aug 2020 (Worldometer 2020). The regional distribution of confirmed infected and deaths are given in the below Fig. 1 and Fig. 2.

Apart from global health risk, the social distancing and unprecedented business closures as a part of policy measure smashed host economies (Chakraborty \& Prasenjit 2020), and fewer economic activity curtails industrial energy consumption, halting traveling activity that refines the environmental quality in terms of lower emissions and restoration of stratosphere Ozone (Zambrano-Monserrate et al. 2020; Tobías et al. 2020; Khan et al. 2020b; Khan et al. 2020c; Collivignarelli et al. 2020). A significant reduction (about 20\%-30\%) of NO2 is observed in the most affected countries such as the USA, China, Spain, France, and Italy (Muhammad et al. 2020; Dutheil et al. 2020); Wang

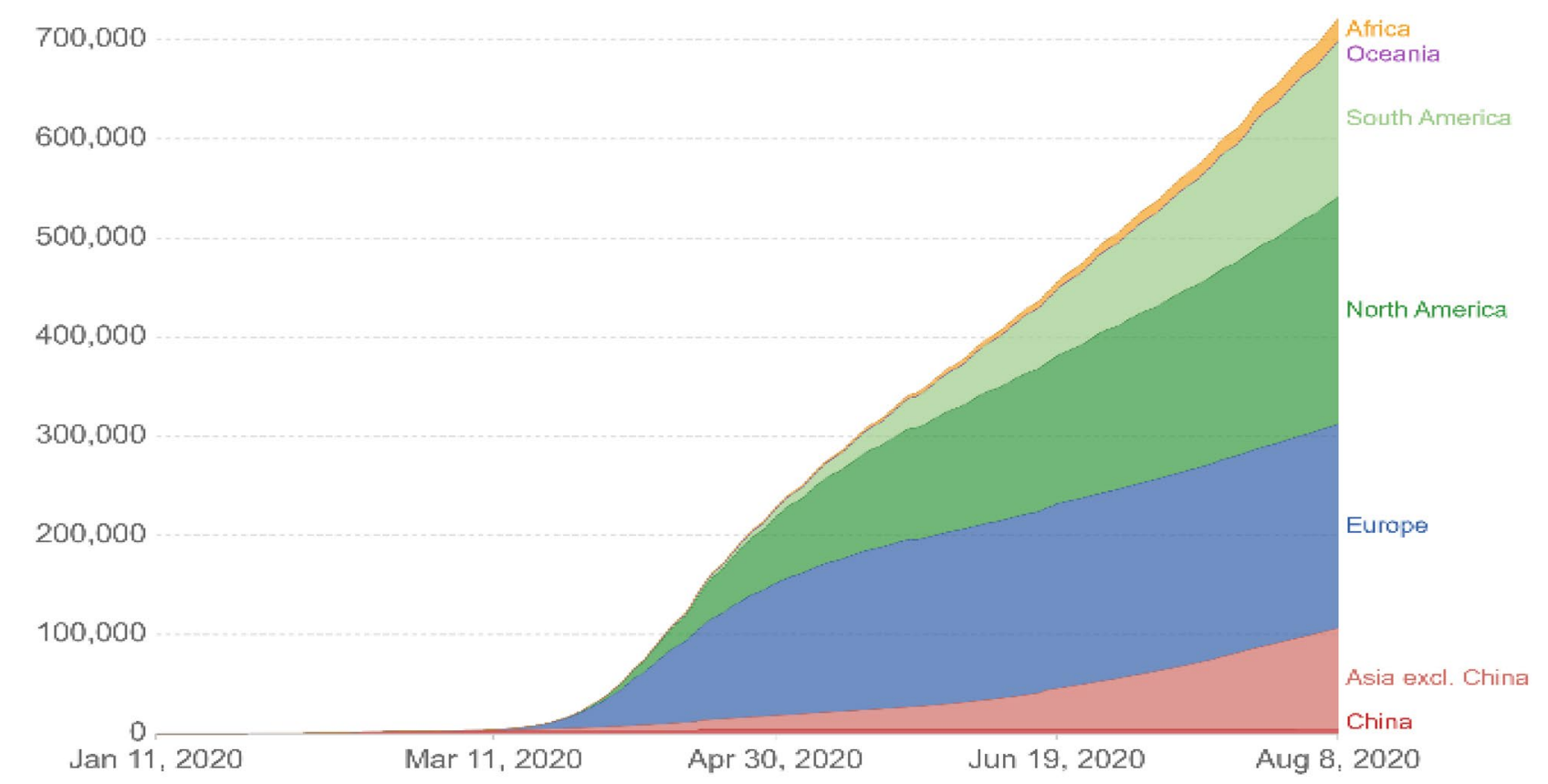

Source: Ourworld database

Fig. 1 Total Number of Confirmed COVID-19 Cases 


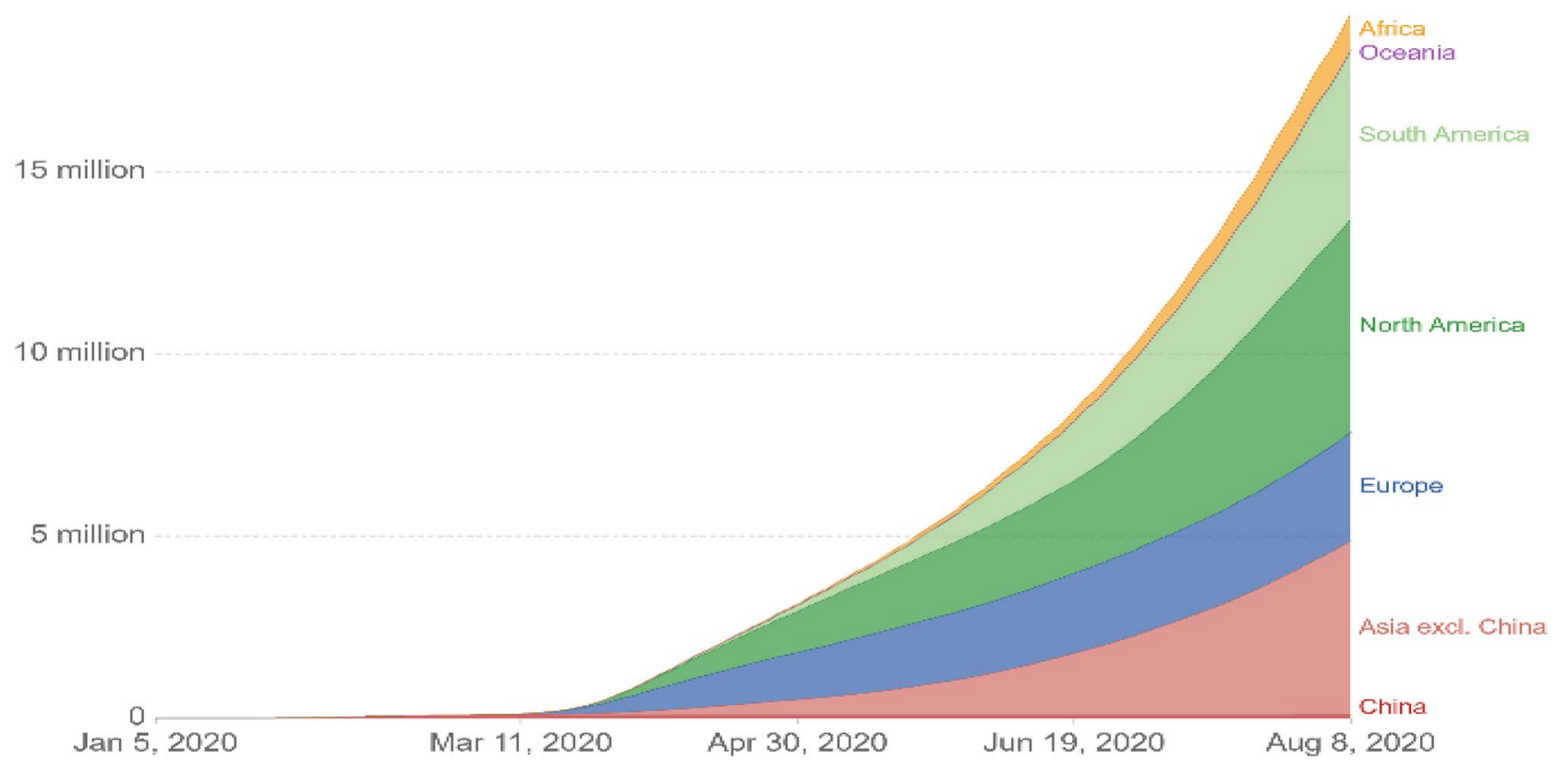

Source: Ourworld database

Fig. 2 Total Number of COVID-19 deaths

and Su 2020). Similarly, Kanniah et al. (2020) proposed that industrial and anthropogenic activities cessation due to COVID-19 lead to a significant reduction of harmful pollutants, which noticeably stemmed from the retrieval of ecosystems. Besides these studies, scientific calculations and satellite images confirm that air pollution in the form of nitrogen dioxide (NO2) emissions has dropped, which fosters the recovering rate of the stratosphere ozone layer (NASA 2020).

The temporary shutdown of global economic activities at once "retune" the ecosystem; however, the impending challenge is much harder than the prevailing one. Whopping unemployment rate and smashing economies around the globe, creating several social hazards that have far beyond the impact on human life and natural balance. COVID-19 turmoil impact on society and economy can be judge through the shrinking of agriculture prices by $20 \%$ due to lower demands from restaurants; Brent Crude dropped by $24 \%$ from $\$ 34 /$ barrel (NPR 2020) to stand at $\$ 25.70$ (Business insider 2020), $1.2 \%$ reduction in Chemical industry the worst growth for the sector since the 2008 financial $\mathrm{crash}^{5}$. Moreover, a survey of the British Plastics Federation (BPF) shows 80\% of respondents anticipated a decline in turnover over the next two quarters, with $98 \%$ admitting concern about the negative impact of the pandemic on business operations (BPF 2020) Table 1 further elaborate on the shrinkages in energy demand due to the closure of business activities across different countries that leads to lower emissions.

Table 1 Reduction in energy demand in the lockdown period

\begin{tabular}{llll}
\hline Country & Lockdown Start & Lockdown End & Energy demand (ED) \\
\hline USA & 22nd March 2020 & 29th May 2020 & ED decrease approx. 9\% to 13\% \\
Australia & 23rd March 2020 & 15th May 2020 & ED decrease approx. 8\% to 10\% \\
Belgium & 18th March 2020 & 19th April 2020 & ED of the industrial and commercial sector decreased by 70\% \\
China & 23rd January 2020 & 8th April 2020 & ED decrease by 8\% (Jan \& Feb compared to the same period in 2019) \\
France & 17th March 2020 & 11th May 2020 & ED decrease by 6\% to 12\% \\
Germany & 20th March 2020 & 20th April 2020 & ED decrease by 4\% to 6\% \\
India & 25th March 2020 & 4th May 2020 & ED decrease by 30\% \\
Italy & 9th March 2020 & 4th May 2020 & ED decrease by 10.1\% in March and 22\% after 22nd March \\
Portugal & 13th March 2020 & 11th April 2020 & ED decrease by 3\% to 5\% \\
\hline
\end{tabular}

Source: (EIA 2020; AEMO 2020; Rajvikram et al. 2020; S\&P Global 2020) 
Although a deceleration in the number of COVID-related deaths has caused some stabilization of oil prices and the stock market, there is still much uncertainty regarding the future of economies. The most devastating fallout of COVID19 is on global poverty. According to the Oxford poverty human initiative (OPHI 2020) estimates that aggregate global multidimensional poverty (MPI) across the 70 countries could increase from 0.095 to 0.125 in 2020 , which is the same value as around 2015. This increase in deprivations because of COVID-19 would set poverty reduction back by 5.2 years, with an additional 237 million people falling into multidimensional poverty across the 70 countries.

It is imperative to recognize the socio-economic impact assessment of COVID-19 to ensure food security, employment, poverty elevation, economic restorations, and sustainable development goal. Economies worldwide are injecting stimulus packages and incentive schemes to improve their inhabitants' socio-economic status, leaving additional debt burden on government deficits; stretching fiscal imbalances, amongst others. This may cause any future economic turmoil/crises; thus, global financial regulators and participating economies need to devise long-term socio-economic policies, where a reasonable investor would allocate to health infrastructure to counter any future set-back while ensuring the country's financial stability.

The next section explains the impact of COVID-19 on environmental pollution and the association between human health and pollution. Chapter three thoroughly evaluates economic fallouts of COVID-19 at a global level. Chapter four briefly explains the social consequences that emerged from the COVID-19. Chapter five concludes the entire discussion and provides policy implications and suggestions for regulatory bodies, the corporate sector, economists, and environmentalists to maintain environmental sustainability and compensate socio-economic losses due to COVID-19, which also paves a way towards sustainable development.

\section{COVID-19: Opportunity to restore environmental sustainability}

A rare benefit of COVID-19 is mainly attributed to the reduction of global pollution and restoration of natural ecology (Zambrano-Monserrate et al. 2020; Tobías et al. 2020; Collivignarelli et al. 2020). Several empirical studies, satellite images, and air quality ground data echo that air pollution in the form of carbon emissions, O3 pollution, nitrogen dioxide emissions, carbon monoxide, amongst other pollutants, are reduced significantly. This also highlights that extreme pollution is a human-made phenomenon, and restoration of nature is imperative, indicating the potential to achieve sustainable production and consumption to avoid such environmental hazards.
Abrupted widespread of the COVID-19 leaves a mark on human socio-economic and ecological aspects. A unanimous lockdown and halted economic activities in China, Europe, and the USA tend to lower emissions that mainly emerged from industrial and transport activity (Shrestha et al. 2020; Zhang et al. 2019; Zhang et al. 2020). In order to minimize the COVID-19 impact, the social distancing and economic discontinuity measure improved terrestrial air quality by 20 to 30 percent in the USA, China, Spain, France, and Italy (Muhammad et al. 2020; Khan and Zhang 2020; Dutheil et al. 2020; Zhang and Khan 2020; Khan et al. 2021; Wang and $\mathrm{Su}$ 2020). In the same vein, Kanniah et al. (2020) confirm a reduction of $\mathrm{O} 3$ pollution in industrial and anthropogenic activities due to cessation of economic activity as a response to widespread cases and deaths of COVID-19 patients. Similar insights are observed from Fig. 3, visualizing that environmental pollution progressively reduced after the closure of economic activity (Shutdown) and reach its minimal level in full shutdown. Figure 4 shows that lockdown measures until 25-April reduce the level of global carbon emissions by $15.1 \%$.

On the other hand, a higher pollutant exaggerates the vulnerability of contagious diseases like SARS, MARS, and COVID-19 in the form of lungs infection and other respiratory disorder, which lead to higher mortality and morbidity rate; thus, pollution creating an overall adverse effect on global public health (Manisalidis et al. 2020; Khan et al. 2019; Khan and Dong 2017b; Pothirat et al. 2019). This phenomenon is empirically tested in Italy by Fattorini et al. (2020), who yields that respiratory diseases worsen in highly polluted cities. Likewise, the medical research also found a strong correlation between air pollution and severe health problems such as chronic obstructive pulmonary disease, breath shortness, and scratchy throat and further lead to worst diseases of lungs such as asthma (Linardon et al. 2020; Martelletti and Martelletti 2020; Khan et al. 2019b; Arjomandi et al. 2018; Khan et al. 2017; Yin and Wunderink 2018; Khan et al. 2018; Khan and Dong 2017; Wilson et al. 2017; Khan 2019; Carugno et al. 2016), which are similar to the indications adhered by novel COVID-19. Figure 5 visualizes the historical fossil fuel consumption globally, representing an increasing trend till 2019. However, after the 2020 COVID-19 lockdown measure, the emissions level dropped sharply.

The COVID-19 exposes the global health system's resistance capacity and infrastructure that highlights the importance of additional public health measures in higher R\&D to deal with contiguous diseases while improving necessary health infrastructure. Moreover, a sustainable economic system with minimal pollution and resource conservation is a prerequisite to increasing people's immunity and resistance. Tough undesirably, nature nowadays is observed as a "retuning" for ecosystem and humans, given the ecosystem a "recuperative time" with decreased interference of humans in the natural environment. For the sake of brevity, some recent empirical studies are concluded in Table 2. 


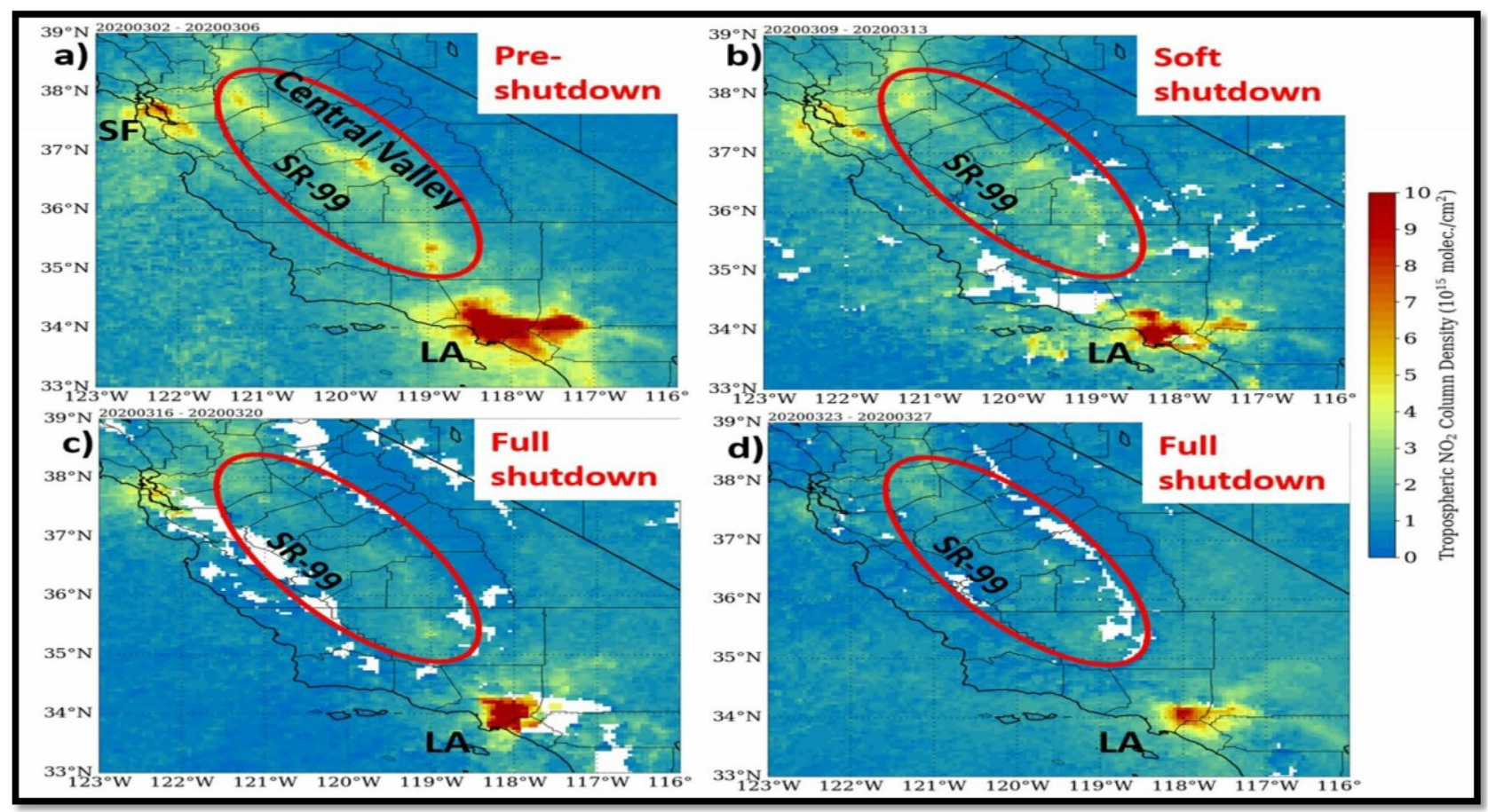

Source: NASA (2020)

Fig. 3 Environmental pollution before and after shutdown

\section{COVID-19 and longlasting economic Losses COVID-19 and longlasting economic losses}

After the global financial crisis, the world economy faced new COVID-19-related obstacles that turned into an economic crisis response to state closures of economic activities. The current pandemic outbreak (COVID-19) has a profound impact on national and foreign economies. Apart from the massive loss of human lives, the world economy has undergone destruction on an unparalleled scale in many economies. COVID-19 may destroy individual livelihoods, companies, markets, and economic activities in general. From $21^{\text {st }}$ February to $24^{\text {th }}$ March 2020, the COVID-19 crisis escalated worldwide, with an increasing number of confirmed cases every day. Numerous organizations are experienced multiple issues with a definite amount of damages. Primarily, companies are suffering a multitude of challenges as a deterioration in demand, interruptions in the Supply chain, revocation of export orders, shortage of raw material, and distortion in transportation networks (Naqvi 2020). However, companies worldwide are witnessing the substantial consequences of the current outbreak on their business operations (World Economic 2020).

Williams (2013) observed that the epidemic diseases severely undermine the country's business operations, as economic activities are highly reliant on money mobilization, which is adversely affected by the current pandemic. The economic and social consequences of the epidemic can be seen in locking cities worldwide, constraints on labor mobility, travel prohibitions, shutdown airline operations, and slowing down economic activities.

COVID-19 would significantly impact developing countries, making it much harder to introduce effective stimulation without experiencing strict foreign exchange restrictions (UNCTAD 2020). The most fragile countries are those with poor health infrastructure, highly reliant on trade and tourism, heavily indebted, and consist of unsteady capital flows (World Bank 2020a). The management of the outbreak of COVID-19 is attempting to revive the economy, but even after 2020, there is still a high risk of continued financial stress until economic activities resume properly. (World Bank 2020a).

The COVID-19 outbreak is anticipated to have substantial implications for overall GDP growth (World Economic, 2020). In the trend, global development is projected to rebound in the second quarter of 2020. In 2021, growth is expected to rise to $5.4 \%$, almost $0.4 \%$ below the April forecast. Consumption is expected to rise next year with strengthening investment steadily. In 2021, the Global GDP as a whole is projected to exceed its point of 2019 . Nevertheless, the IMF predicts this year's global economy 


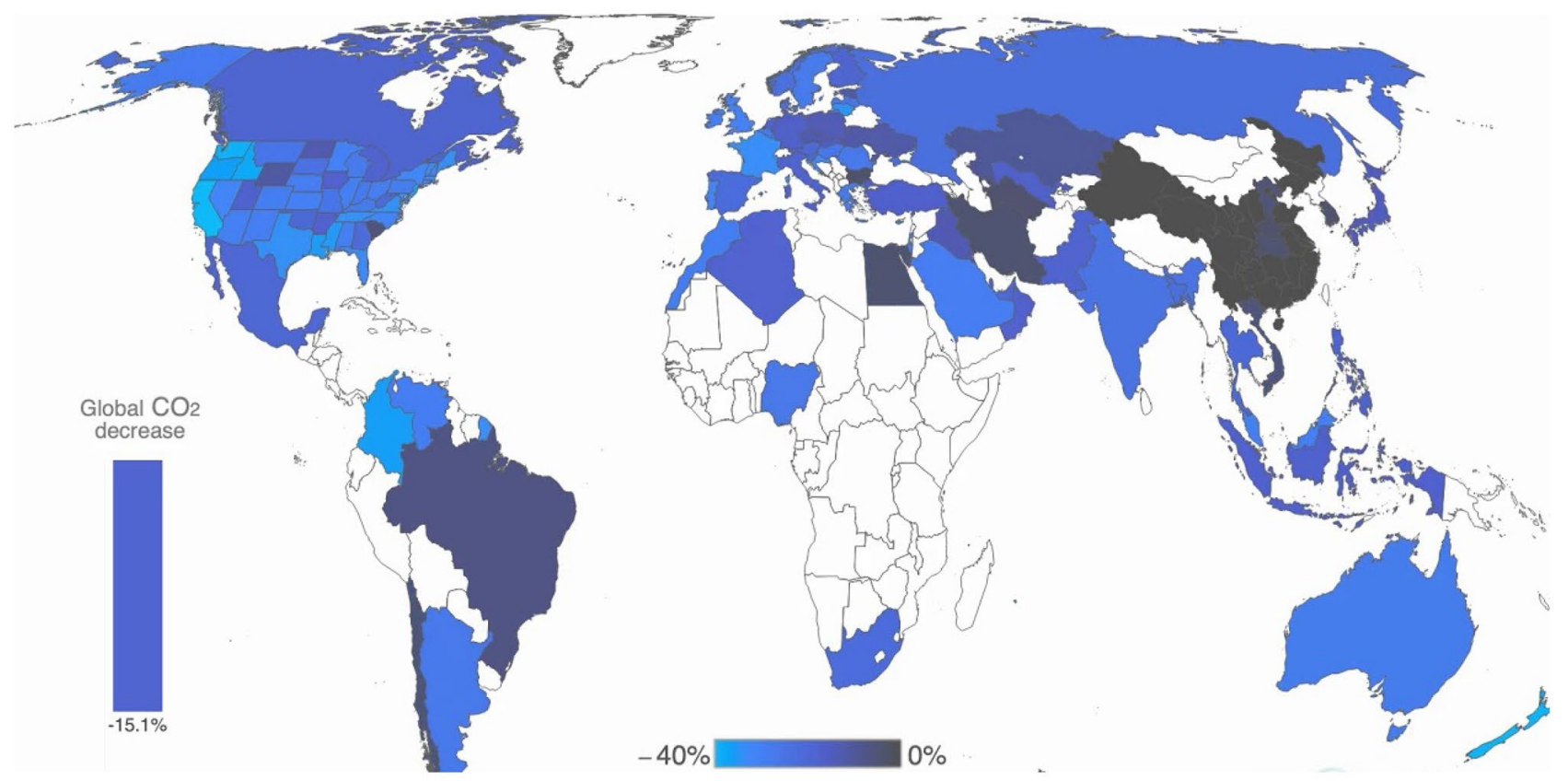

Source: Global Carbon Project 2020

Fig. 4 Changes in CO2 emissions (during the COVID-19 forced confinement)

will diminish by $3 \%$. Figure 6 exhibits the projected GDP growth indicating an increasing trend in COVID-19 and a progressive recovery in the subsequent quarter.

While it said the COVID-19 pushed the planet into a "crisis like no other," it predicted that global economic growth would accelerate to $5.8 \%$ next year if the outbreak disappeared in the second half of 2020 (IMF 2020). Recovery in major services-related economies, such as the UK or Italy, severely affected by the outbreak anticipated being a slow process. The growth rate in 2021 for developed and emerging markets is anticipated to accelerate to $5.9 \%$, mainly reflecting China's revival forecast ( 8.2 percent). The group's growth rate, excluding China, is forecast to be $5.0 \%$ in 2020 and $4.7 \%$ in 2021, leaving 2021 GDP marginally below its 2019 rate for this segment of emerging markets and developing economies (Economics 2020). Table 3 compiles real GDP growth comparison with corresponding past and projected future values.
Fig. 5 Global daily fossil $\mathrm{CO} 2$ emissions

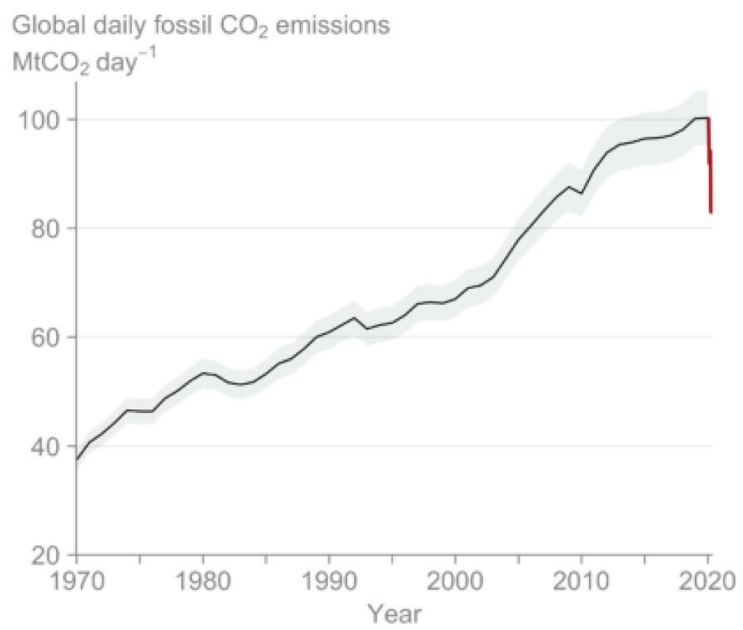

Nature Climate Change (2020); Global Carbon Project

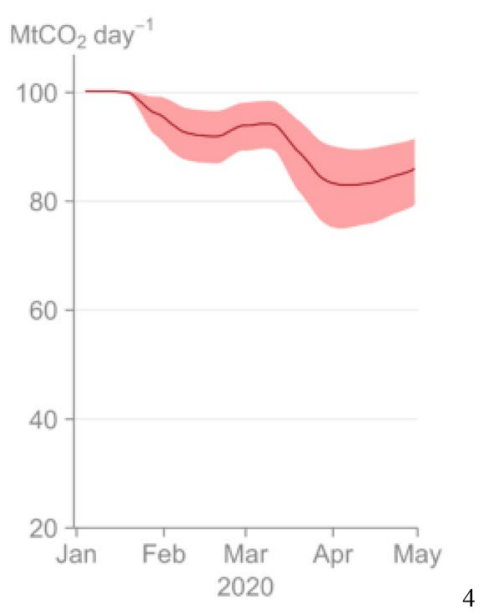




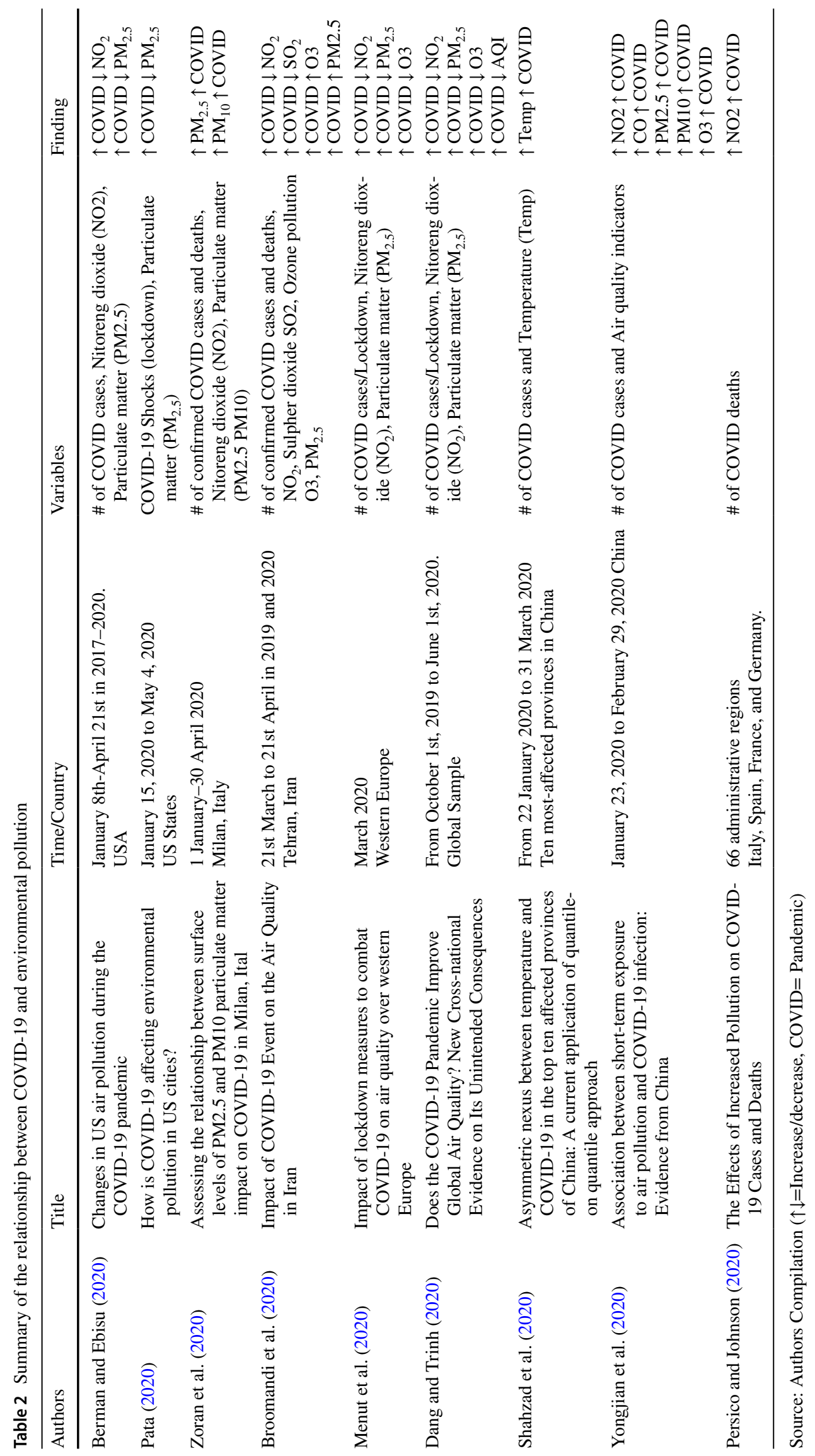



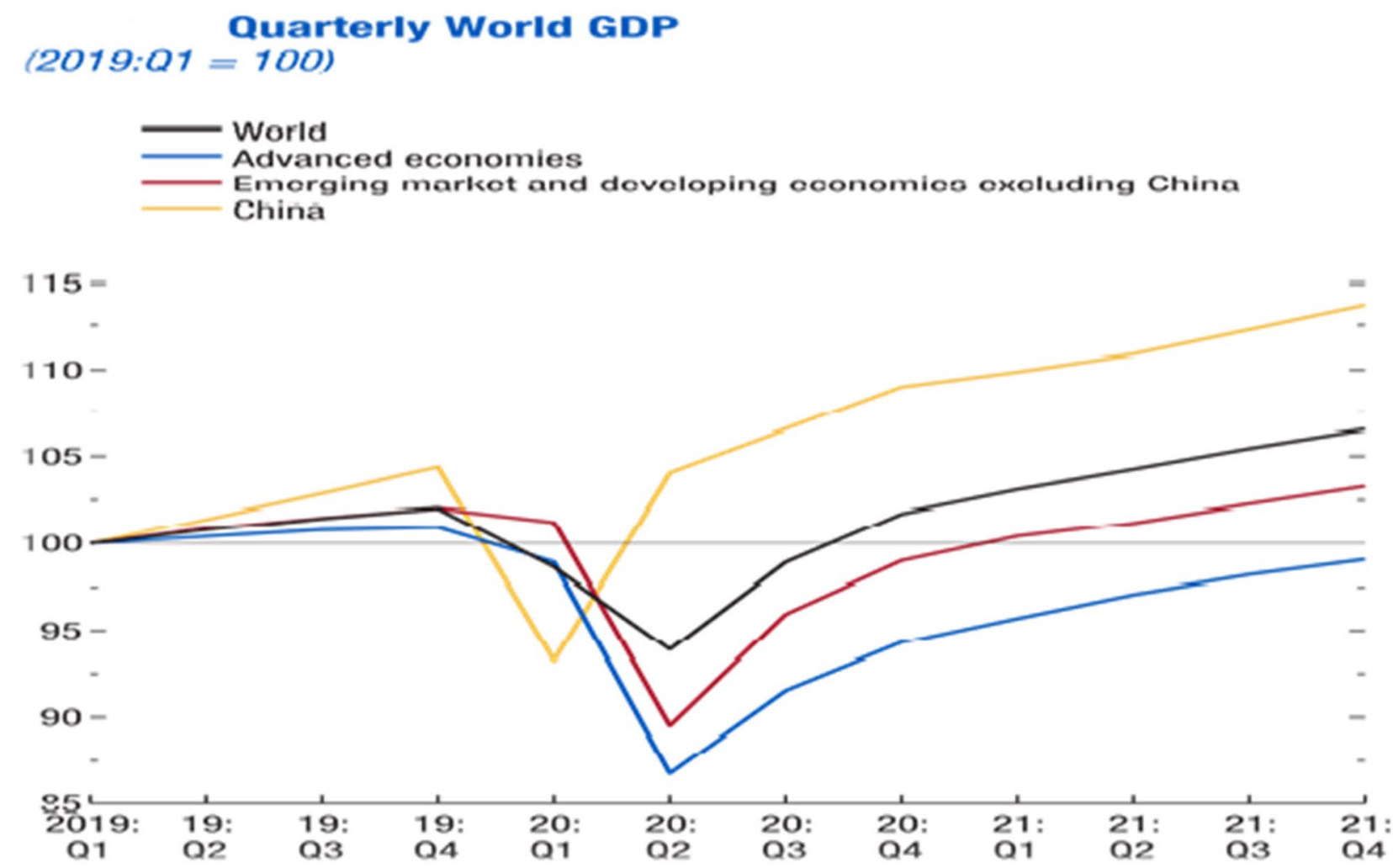

Source: IMF 2020

Fig. 6 Projected GDP growth before and after COVID-19 crises

The global COVID-19 outbreak is anticipated to impact global GDP between 2.3\% and 4.8\% (ADB 2020). This persistent epidemic has also been projected to decline overall FDI by $5 \%$ to $15 \%$ (UNDP 2020b). UNCTAD report stated that the world desperately required a $\$ 2.5$ trillion support package to deal with the damages (UNDP 2020a). Therefore, the current global recession is expected to be much worse than the crisis of 2008 (UNCTAD 2020). Also, the International Labor Organization (ILO) found that around 25 million people worldwide could lose their jobs (income losses of workers as high as US\$ 3.4 trillion) (ILO 2020b). Developing countries' income losses are expected to reach \$220 billion (UNDP 2020b).

Moreover, World Bank anticipated that South Asia might appear in its worst economic outlook in 40 years, as almost half of the nations dropped into severe recession (World Bank 2020b). Worldwide businesses, regardless of scale, dependent on China's materials, have begun to experience production contractions. Suspension of transport channels between countries further hindered global economic activity. Furthermore, some customer and company turmoil has disrupted normal business trends and generated market anomalies.

The business activities of micro, small, and mediumsized enterprises are the primary victim of COVID-19.
Compared to large enterprises, they typically lack adequate resources, particularly monetary and managerial resources, and therefore are not equipped for these shocks that are persistent in staying longer than anticipated (Bartik 2020). Moreover, access to labor, production stagnation, raw material shortages, and transportation constraints would significantly affect these enterprises.

\section{The social disruption of COVID-19}

The COVID-19 pandemic has headed all suffered economies worldwide to unprecedented action, trade interruptions, and an intense global economic crisis. These all challenge the supply of essential medicines and other resources. The distributors' export restrictions of both COVID and non-COVID goods, i.e., India, banned various critical active pharmaceutical ingredients (APIs) and finished products, while these restrictions have since been revoked in the UK, similar exports have been suspended. Moreover, medicines' slow production process severely exaggerated many countries (Anthony McDonnell 2020). The COVID19 pandemic has raised a sophisticated threat to Healthcare worldwide. In general, healthcare Workers are facing one 
Table 3 Real GDP Growth (Past, Current and Projected)

\begin{tabular}{|c|c|c|c|c|c|c|}
\hline \multicolumn{4}{|c|}{$\begin{array}{l}\text { Selected Economies Real GDP Growth } \\
\text { (Percent Change) }\end{array}$} & \multicolumn{2}{|c|}{ Projections } & $\begin{array}{l}\text { The difference from } \\
\text { April } 2020 \text { WEO Projec- } \\
\text { tions 1/ }\end{array}$ \\
\hline & 2018 & 2019 & 2020 & 2021 & 2020 & 2021 \\
\hline Argentina & -2.5 & -2.2 & -9.9 & 3.9 & -4.2 & -0.5 \\
\hline Australia & 2.8 & 1.8 & -4.5 & 4.0 & 2.2 & -2.1 \\
\hline Brazil & 1.3 & 1.1 & -9.1 & 3.6 & -3.8 & 0.7 \\
\hline Canada & 2.0 & 1.7 & -8.4 & 4.9 & -2.2 & 0.7 \\
\hline China & 6.7 & 6.1 & 1.0 & 8.2 & -0.2 & -1.0 \\
\hline Egypt 2/ & 5.3 & 5.5 & 2.0 & 2.0 & 0.0 & 2.8 \\
\hline France & 1.8 & 1.5 & 12.5 & 7.3 & -5.3 & 2.8 \\
\hline Germany & 1.5 & 0.6 & -7.8 & 5.4 & -0.8 & 0.2 \\
\hline India 2/ & 6.1 & 4.2 & -4.5 & 6.0 & -6.4 & -1.4 \\
\hline Indonesia & 5.2 & 5 & -0.3 & 6.1 & -0.8 & -2.1 \\
\hline $\operatorname{Iran} 2 /$ & -5.4 & -7.6 & -6 & 3.1 & 0.0 & 0.0 \\
\hline Italy & 0.8 & 0.3 & 12.8 & 6.3 & -3.7 & 1.5 \\
\hline Japan & 0.3 & 0.7 & -5.8 & 2.4 & -0.6 & -0.6 \\
\hline Kazakhstan & 4.1 & 4.5 & -2.7 & 3.0 & -0.2 & -1.1 \\
\hline Korea & 2.9 & 2.0 & -2.1 & 3.0 & -0.9 & -0.4 \\
\hline Malaysia & 4.7 & 4.3 & -3.8 & 6.3 & -2.1 & -2.7 \\
\hline Mexico & 2.2 & -0.3 & 10.5 & 3.3 & -3.9 & 0.3 \\
\hline Netherlands & 2.6 & 1.8 & -7.7 & 5.0 & -0.2 & 2.0 \\
\hline Nigeria & 1.9 & 2.2 & -5.4 & 2.6 & -2 & 0.2 \\
\hline Pakistan 2/ & 5.5 & 1.9 & -0.4 & 1.0 & 1.1 & -1.0 \\
\hline Philippines & 6.3 & 6.0 & -3.6 & 6.8 & -4.2 & -0.8 \\
\hline Poland & 5.3 & 4.1 & -4.6 & 4.2 & 0.0 & 0.0 \\
\hline Russia & 2.5 & 1.3 & -6.6 & 4.1 & -1.1 & 0.6 \\
\hline Saudi Arabia & 2.4 & 0.3 & -6.8 & 3.1 & -4.5 & 0.2 \\
\hline South Africa & 0.8 & 0.2 & -8.0 & 3.5 & -2.2 & -0.5 \\
\hline Spain & 2.4 & 2.0 & 12.8 & 6.3 & -4.8 & 2.0 \\
\hline Thailand & 4.2 & 2.4 & -7.7 & 5.0 & -1.0 & -1.1 \\
\hline
\end{tabular}

Source: IMF-World Economic Outlook-June 2020

of the world's most disadvantaged health issues. High healthcare prices, shortage of safety equipment like N95 Masks, and low ICU beds and ventilators determined vulnerabilities in patient care quality.

Although the outbreak's economic effect persists and becomes more and more volatile, it is quite clear that developing thrifts will be unexceptional before it is strengthened. (UNCTAD 2020). However, poverty is projected to be raised at approx. 11 million people. (World Bank 2020a). The pandemic of COVID-19 gradually became the greatest economic and human catastrophe in our lives, spreading to all nations. The pandemic's consequences affected the most fragile and pushing them behind. The United Nations report found that COVID-19 has reversed the growth of poverty, Healthcare, and education. During the short period, the COVID-19 pandemic triggered an extraordinary disaster, causing more damage to Sustainable development, with the world's poor and vulnerable most affected (United Nations 2020). A more recent ILO study indicates that 81 percent, or approximately 2.7 billion employees, of all global employees (ILO) are affected by the lockdown (ILO 2020a). Figure 7 displays the strike in unemployment between 2019 and 2020.

According to the IMF (2020), the share of unemployed people in the United States reached 10.4 percent and marked the end of this decade of growth as one of the world's leading economies. Millions of the workforce have also been placed into government-supported job protection schemes as economic sectors such as tourism or hospitality have been shut down (Jones 2020). Moreover, the COVID19 economic downturn badly hit women's workforces and create an anomaly of gender inequality. Unlike previous crises, women's employment is a considerable risk than men's, mainly due to the service sector's downturn. 
Fig. 7 Countries with the striking unemployment rate

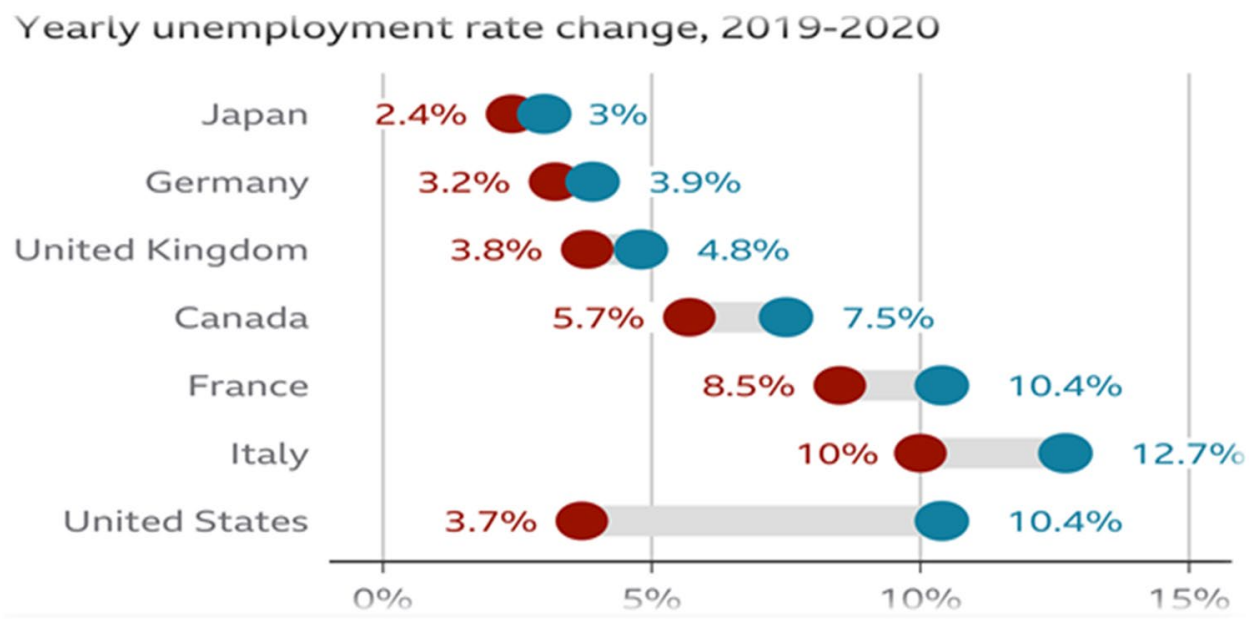

Sources: IMF-World Economic Outlook- June 2020.
Simultaneously, women represent a significant proportion of front-line employees, particularly in the health and social care sectors.

Furthermore, the increased burden of unpaid treatment caused by disasters affects women more than men. Until the COVID-19 crisis, 1.3 billion or $44.3 \%$ of women worldwide were employed, compared to 2 billion or $70 \%$ of men (ILOSTAT 2020). However, economic downturns impact males more than females, considering that males appear to be involved by industries closely linked to economic cycles (e.g., construction and production), while in industries less vulnerable (e.g., health care and education), females dominate. The economic downturn of COVID-19 varies from previous crises, considering that industries desensitized to economic instability absorb a significant proportion of female jobs. In 2020, 527 million women work in these industries, comprising $41 \%$ of total female jobs than $35 \%$ of total male jobs. This means that the current epidemic is likely to upset women's jobs more severely than men's (ILOSTAT 2020). Since the COVID-19 crisis has a substantial impact in specific ways on women workers, there is a possibility that some developments from these decades will be reversed, and gender inequalities intensified in the labor market. Figure 8 shows the global status of vulnerable employees due to lower wages and fewer working hours.

COVID-19 reforms trigger haphazard conditions in many of the world's counterparts, resulting in scarcity of food for consumption, contributing to rising food prices across countries that ultimately curtail the general public's purchasing power. Even though the distortion in the global supply chain of food has gained public interest. The influence of the current pandemic on agricultural output has not been fully understood; most current studies are based on logistics and supply of goods FAO (2020a); Gong (2020); Gray (2020); Reardon (2020). Throughout the outbreak, typical offline distribution networks were ineffective. Also, on one side, the short-term demand for agricultural products collapsed due to the quarantine policy. "Closed community/
Fig. 8 Share of employment currently at high-risk of reduction in working hours, cuts to wages and layoffs, by sex, 2020

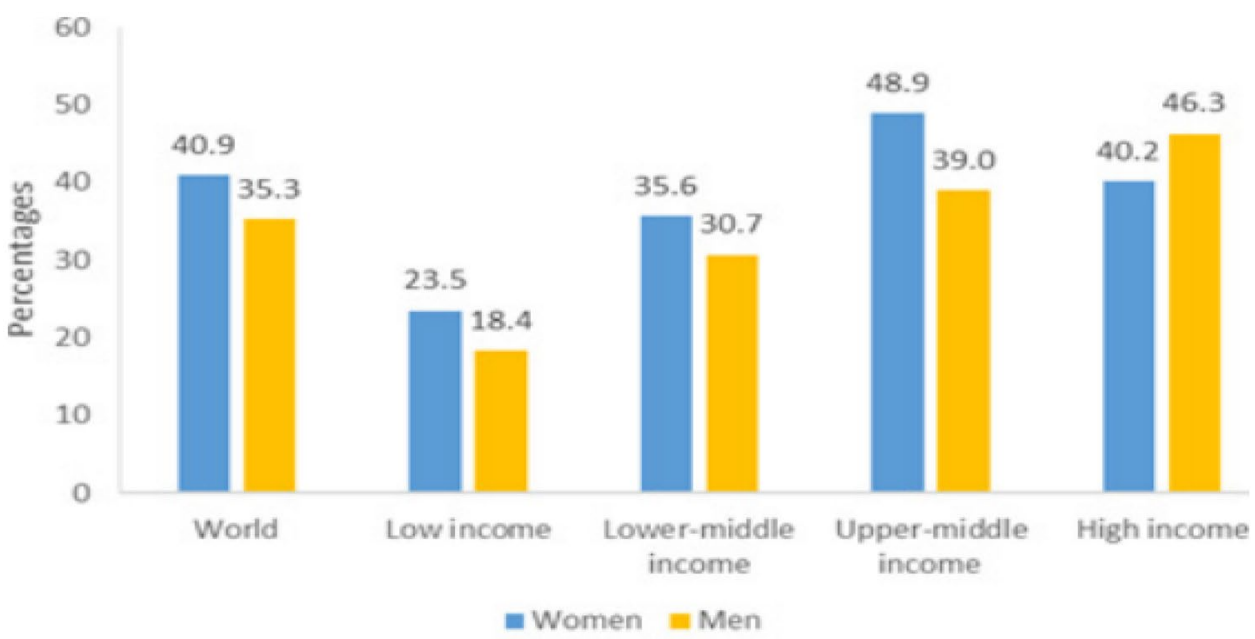

Source: ILO calculations based on ILO. 
village management" and "outdoor family restrictions" laws drastically reduced recurrence rates and outside consumption. The closing of traditional urban sales departments compelled buyers not to purchase as intended. On the other hand, due to logistics restraints, supply chains were shattered. Both interregional and intra-regional logistics instantly gave way to medical workers and supplies.

China's lessons revealed that the shutdown of people's activities/movements against COVID-19 interrupted production in all affected economies. That is a substantial hazard to the long-term food supply (FAO 2020b). However, such cases are not only observed in China but also in other economies. This revealed that the extensive pandemic had a more significant effect on unpreserved agricultural output. Although the prevention and control measures disrupted the existence growth cycle of agricultural goods, further disrupting regular food supply cycles and rising medium-term market volatility. In Asia, where the population is enormous, and the demand for essential grain is exceptionally inelastic. Lower supply may lead to higher prices. Additionally, the current epidemic might perhaps accelerate the swing of the "double season" rice crop system into a "single season," a long-term threat to overall production and lead towards an extreme shortage of food (Qiu 2020).

Figure 9 shows the spatial distribution of multidimensional poverty across the globe. The dark red color indicates higher multidimensional poverty in most of the COVID-19 affected countries, among others.

\section{Conclusion and policy implications}

SARS-COV-2 pandemic has truly transformed the world, sparing no country in its path; the communicable disease due to globalization spread quickly worldwide. To prevent the spread, governments worldwide are propagating; 20s soap water handwash, facial cover (mouth and nose), sanitizer, social distancing (avoid crowded places), avoid contact with sick people, and the stricter countermeasure includes lockdowns and smart lockdowns. The world is trying to adjust as the impact has been on all three P's: profit, people, and the planet. Profit and people are negatively affected; however, COVID-pandemic has been a blessing in disguise for the planet.

The lockdowns are the most strict measure to counter the communicable disease, restricting public movement. In this restriction, a stark decline is observed in consumer demand for both tangibles and intangibles products. The effect is demand and supply and the restriction of idle factories to protect the massive workforce infected with the deadly virus. Businesses are now at a standstill and even fear closure permanently. In the aviation industry, the International Air Transport Association (IATA) is expected to book a loss of US\$ 84 billion in 2020, with hundreds and thousands lay off (Khan et al. 2021b; IATA 2020).

The societal impact because of movement restriction is affecting public mental and physical health. Work from home is new for employees whose social-economic conditions are better. The work from home and

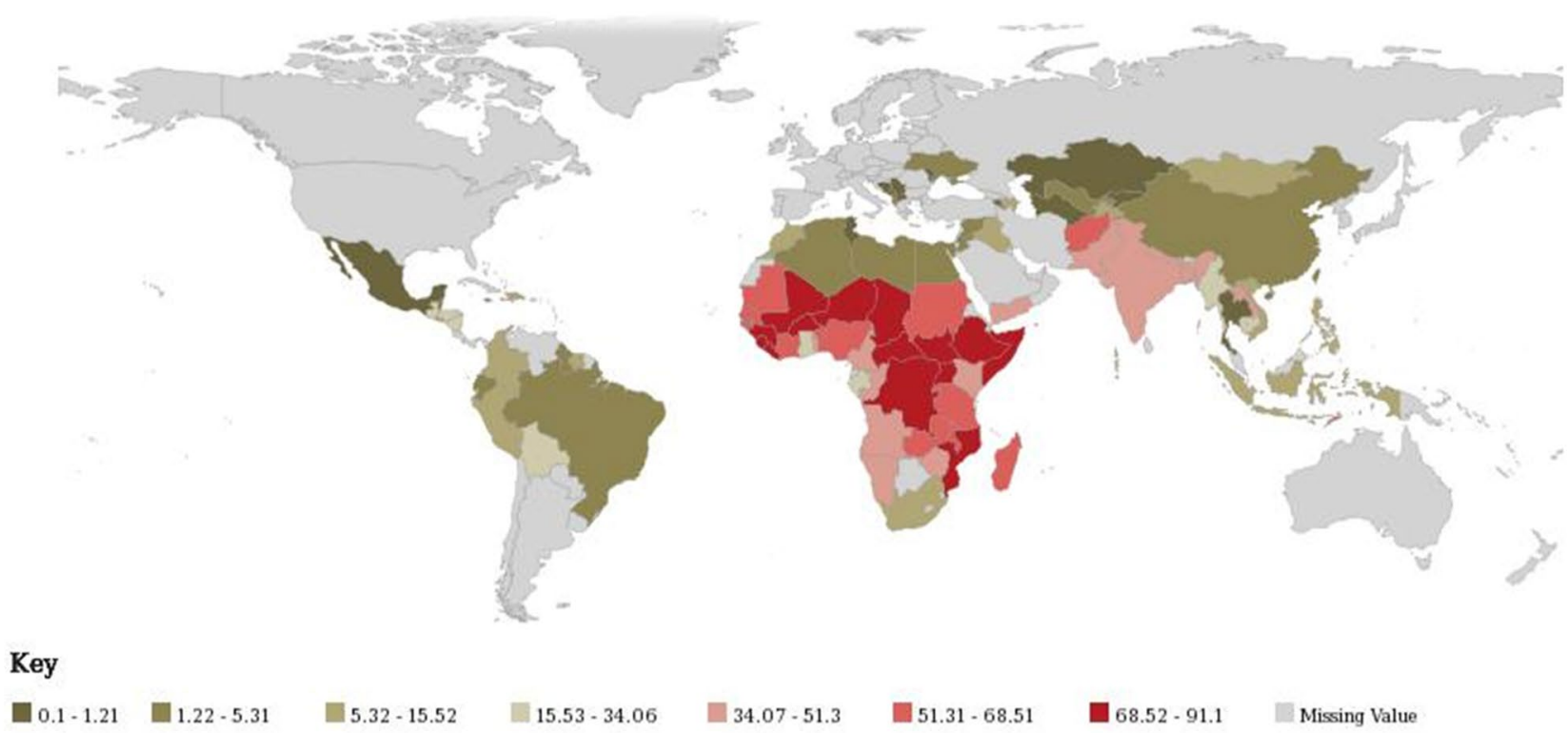

Source: OPHI, 2020

Fig. 9 Spatial distribution of Multidimensional poverty $(\mathrm{H})(\%)$ 
unemployment in the pandemic will result in a high fertility rate worldwide. Husbands and wives and partners now have more time to think to increase their family. The other reason for a higher rate is less awareness of contraceptives and education in developing countries. A disturbing trend that is also observed in COVID extended lockdowns is the high rate of divorces. The measure of social distancing has its fallout, too; people cannot socialize, which has psychological consequences like violence and early stages of depression.

The most troublesome societal impact is on patients with severe ailment who needs cancer radiation therapy, kidney dialysis, or children with routine vaccination and pregnant mothers are one of few such examples. Hospital logistics faces failure in both developed and developing countries as the current health system has collapsed. The food supply and education sector are also severely affected; countries and cities have good technological infrastructure coped by conducting online classes in schools and universities. Food supply, although it is still a looming crisis in densely populated cities. However, as time pass, governments and corporates are learning to handle food logistics. Due to less supply of commodities, prices have risen. Along with the price hike of essential goods, there is an observable escalating unemployment rate to a dangerous level globally and, as a result, climbing crime rate.

Government lockdown has been a blessing in disguise for the planet and environment, the only positive impact observed by researchers. Hard facts prove that air quality worldwide has improved with decreasing $\mathrm{CO} 2$ emissions. As a result, a sharp decline of 3 to $4 \mathrm{C}$ is recorded, and ozone in many parts of the world is repaired due to less air pollution. The main reason for fewer carbon emissions is the closure of non-essential factories, restriction on air travel, and the ban on public transport for the daily commute. Oceans and lakes ecosystems are globally repaired due to less traffic. Medical waste is the only negative on the environment, as PE dresses and disposal mask usage has increased many folds, PE used by medical staff and disposable facial masks. The positive impact on the environment is significant in contrast to medical wastages. Air quality test results make headlines and much relief for the public to breathe fresh air (Picheta 2020). However, it is pertinent to mention that the repair is for till lockdowns are in place. In this COVID pandemic, the only good news is that the Himalayas are visible for the first time in 50 years, quite welcoming and remembered.

We suggest government officials, Healthcare personal, and environmentalists worldwide the following short term actions and long term strategies fight the COVID pandemic more effectively:

\subsection{Short term actions}

1. To immediately form a pandemic task force, enabling them with technology and human resource. The task force will serve as an anchor for all the coordinated actives needed to countermeasure the pandemic. As the decision making will be centralized, the multi-echelon network can easily balance the essential requirements of food and medical items in the whole system. Further correct information at the right time can be shared with all stakeholders.

2. Regional food and medical supply warehouses and small distributions centers are needed to be built in public parks or at the center of the cities for efficient distributions in densely populated areas.

3. Health care facilities should be mobilized; lorries, cars, and motorbikes can be used for the purpose. Motorbikes can be most effective in densely populated areas, quickly responding to any emergency.

4. Smart lockdown is the most effective measure which can help the economy and prevent further spread. The only area which is affected the most be quarantine and people in other areas with necessary measures (facial mask and social distancing) can operate with ease.

5. AAA (accessible, affordable, and available) communication should be provided to the masses. $3 \mathrm{G}$ or $4 \mathrm{G}$ internet technology is most suited for the purpose. AAA communication can help authorities to connect and assist the public during emergencies. Cellular technology and smartphones are the most reliable.

6. Telehealth portals' formation can reduce pressure on hospitals as sick patients can avoid going to the already stressed health system due to COVID infection.

7. Agri emergency on the essential item is also an important step to prevent any shortage during the COVID crisis as the crisis global, and all agri-exporting countries are still recovering from lockdowns.

8. TTT (track, trace, and test) for early COVID detection has been very effective and should be implemented in every country. This will also assist in smart lockdowns, and businesses in areas with no infections can function normally.

9. Combine testing of 20 or more suspected COVID patients can reduce overall testing costs. A large population can be tested in less time.

10. Mobile Testing should be conducted to identify most infected areas in cities, which help in smart lockdown and health personal can better focus as per data.

11. Awareness campaigns with NGOs' help should start on all mediums, so people can better care and help to stop the spread. Rural areas in developing countries are always not well connected. Person to person interaction by a health worker would guide for better prevention. 


\subsection{Long Term Strategies}

1. Disaster management is now the most important matter at hand. Countries need to enact laws and built provisions to deal with such calamity in the future. An organized agency should be established to handle matters more efficiently.

2. The collection of public data is essential to organize healthcare and food supply activities. However, privacy laws in many countries prevent the government from collecting any such information. This should be handled amicably, removing any public mistrust in the exercise. Encrypted data and blockchain will be beneficial, as ledgers will not easily be decoded to extract personal information.

3. Reshoring of essential items should, for some items, be planned to avoid any food and medical shortages. Laws should be made for ease of business.

4. Food logistics is the most neglected of all areas, which has caused crises during the COVID pandemic. Permanent regional distribution centers must be an integral part of city planning.

5. Water and sanitation need improvement, especially in developing countries. Budget and designated offices should overlook the system for a continuous supply. Countries with coastal areas should use seawater by adopting desalination filtration technology for continuous water supply, drinking, or personal hygiene.

6. Environmental gains that the world has yielded should not be forgone, and laws must be enacted to keep the pace steady. During the lockdown, power consumption has risen, and the world needs an alternate source of clean energy. The most reliable and ecofriendly source is the sun. Countries should levy taxes on furnace oil and coal to discourage use. The collected tax amount should be spent to make solar technology more affordable. If a country does not possess such scientific infrastructure, tech companies should be engaged to import technology, which trains locals for self-sustenance.

7. Air is another clean source for power production and should be exploited. Coastal areas are the best site selection for such installations.

8. Transport and automobile are some of the contributors to carbon emission. Developing countries must improve public transport to reduce air pollutions. City Governments should encourage the use of circular trains by keeping fare low. The government should encourage companies to invest in eco-friendly electric cars and motorbikes to reduce carbon emission further since the global temperature has reduced to 3 to $5 \mathrm{C}$, which is very encouraging and motivating.
9. Countries must rethink city planning; densely populated areas should be replanned to avoid any such calamity in the future. If the population influx from a rural area is work-related, more opportunities should be provided, so population influx should stop, putting less burden on city infrastructure.

10. Countries with the tourism industry should opt for seasonal tourism only. Seasonal tourism will allow the ecosystem to repair. Environmental test results in the COVID pandemic is clear evidence that people are the most anthropogenic stressors.

\section{References}

Arjomandi M et al (2018) Respiratory responses to ozone exposure. MOSES (the multi- center ozone 379 study in older subjects). Am J Respir Crit Care Med 197:1319-1327

Allocati N, Petrucci AG, Di Giovanni P et al (2016) Bat-man disease transmission: zoonotic pathogens from wildlife reservoirs to human populations. Cell Death Dis 2:16048

ADB (2020) Asian development outlook: What drives innovation in Asia? Special topic: The impact of the coronavirus outbreakAn update. Asian Development Bank. Asian Development Bank, Manila, Philippines

Anthony McDonnell KC (2020) Understanding the impact Of COVID19 on essential medicine supply chains. Center for Global Development

Awan U, Kraslawski A, Huiskonen J (2018) Governing interfirm relationships for social sustainability: the relationship between governance mechanisms, sustainable collaboration, and cultural intelligence. Sustainability 2018(10):4473

Awan U, Khattak A, Rabbani S, Dhir A (2020) Buyer-Driven knowledge transfer activities to enhance organizational sustainability of suppliers. Sustainability 12:2993

Bai Y, Yao L, Wei T, Tian F, Jin D-Y, Chen L et al (2020) Presumed asymptomatic carrier transmission of COVID-19. Jama 323:1406-1407

Bank W (2020a) East Asia and Pacific in the time of COVID-19. East Asia and Pacific economic update (April). Washington, DC.: World Bank

Bank W (2020) South Asia economic focus, spring 2020: The cursed blessing of public banks. World Bank, Washington, DC.

Bartik AB (2020) How are small businesses adjusting to COVID-19? Early evidence from a survey Harvard Business. School Working Paper., 20(102), 1-37

Berman JD, Ebisu K (2020) Changes in US air pollution during the COVID-19 pandemic. Sci Total Environ 739:139864. https://doi. org/10.1016/j.scitotenv.2020.139864

Broomandi P, Karaca F, Nikfal A et al (2020) Impact of COVID-19 event on the air quality in Iran. Aerosol Air Qual Res 20:

Collivignarelli MC, Abbà A, Bertanza G, Pedrazzani R, Ricciardi P, Miino MC (2020) Lockdown for CoViD-2019 in Milan: what are the effects on air quality? Sci. Total Environ. 732:139280. https://doi.org/10.1016/j.scitotenv.2020.139280

Chakraborty I, Prasenjit M (2020) COVID-19 outbreak: Migration, effects on society, global environment and prevention. Sci. Total Environ. 728, 138882. doi: 10.1016/j.scitotenv.2020.138882

Carugno M, Consonni D, Randi G et al (2016) Air pollution exposure, cause-specific deaths and hospitalizations in a highly polluted Italian region. Environ Res 147:415-424 
Dang H-AH, Trinh T-A (2020) Does the COVID-19 pandemic improve global air quality? New cross-national evidence on its unintended consequences, GLO Discussion Paper

Dutheil F et al (2020) COVID-19 as a factor influencing air pollution? Environ Pollut 263:114466. https://doi.org/10.1016/j. envpol.2020.114466

Economic W (2020) World economic prospects monthly. Economic Outlook. World Economy. Vol. 44, Issue 2

FAO (2020a) The FAO food price index. World Food Situation. Released date: 2 April

FAO (2020b) COVID-19 and the risk to food supply chains: how to respond? . Rome

Fan Y, Zhao K, Shi ZL et al (2019) Bat coronaviruses in China. Viruses 11, 210. associated particulate matter: a preliminary study. Sci. Total Environ. 479:109-116

Fattorini D, Regoli F (2020) Role of the chronic air pollution levels in the Covid-19 outbreak risk in Italy. Environmental Pollution 264:114732

Gong BZ (2020) A balance act: minimizing economic loss while controlling novel coronavirus pneumonia. J Chin Gov, 1-20

Gray R (2020) Agriculture, transportation, and the COVID-19 crisis. . Can J Agric Econ, 1-5

Huang C, Wang Y, Li X, Ren L, Zhao J, Hu Y et al (2020) Clinical features of patients infected with 2019 novel coronavirus in Wuhan, China. Lancet 395, 497-506. https://doi.org/10.1016/ S0140-6736(20)30183-5

ILO (2020a) COVID-19 and the world of work: Updated estimates and analysis. ILO Monitor (2nd edition). International Labour Organization

ILO (2020b) COVID-19: Protecting workers in the workplace. . International Labour Organization.

ILOSTAT (2020) ILO: A quantum leap for gender equality: for a better future of work for all. ILO Department of Statistics

IMF (2020) International Monetary Fund . International Monetary Fund

Jones L, PD (2020) Coronavirus: A visual guide to the economic impact. BBC News. Retrieved from https://www.bbc.com/news/ business-51706225

Kanniah KD, Kamarul Zaman NAF, Kaskaoutis DG, Latif MT (2020) COVID-19's impact on the atmospheric environment in the Southeast Asia region. Sci Total Environ 736:139658. https://doi.org/10.1016/j.scitotenv.2020.139658

Khan SAR (2019) The nexus between carbon emissions, poverty, economic growth, and logistics operations-empirical evidence from southeast Asian countries. Environ Sci Pollut Res 26(13): 13210-13220

Khan SAR, Jian C, Zhang Y, Golpîra H, Kumar A, Sharif A (2019b) Environmental, social and economic growth indicators spur logistics performance: From the perspective of South Asian Association for Regional Cooperation countries. J Clean Prod 214:1011-1023

Khan SAR, Qianli D (2017) Impact of green supply chain management practices on firms' performance: an empirical study from the perspective of Pakistan. Environ Sci Pollut Res 24(20):16829-16844

Khan SAR, Qianli D (2017b) Does national scale economic and environmental indicators spur logistics performance? Evidence from UK. Environ Sci Pollut Res 24(34):26692-26705

Khan SAR, Qianli D, SongBo W, Zaman K, Zhang Y (2017) Travel and tourism competitiveness index: The impact of air transportation, railways transportation, travel and transport services on international inbound and outbound tourism. J Air Transp Manag 58:125-134

Khan SAR, Sharif A, Golpîra H, Kumar A (2019) A green ideology in Asian emerging economies: From environmental policy and sustainable development. Sustain Dev 2(6):1063-1075
Khan SAR, Yu Z, Sharif A, Golpîra H (2020b) Determinants of economic growth and environmental sustainability in South Asian Association for Regional Cooperation: evidence from panel ARDL. Environ Sci Pollut Res 27(36):45675-45687

Khan SAR, Yu Z, Belhadi A, Mardani A (2020c) Investigating the effects of renewable energy on international trade and environmental quality. J Environ Manage 272:111089

Khan SAR, Yu Z, Golpira H, Sharif A, Mardani A (2021) A stateof-the-art review and meta-analysis on sustainable supply chain management: Future research directions. J Clean Prod $278: 123357$

Khan SAR, Zhang Y (2020) Assessing the eco-environmental performance: an PLS-SEM approach with practice-based view. Int J Logist Res Appl. https://doi.org/10.1080/13675567.2020. 1754773

Khan SAR, Zhang Y, Anees M, Golpîra H, Lahmar A, Qianli D (2018) Green supply chain management, economic growth and environment: A GMM based evidence. J Clean Prod 185:588-599

Khan SAR, Zhang Y, Kumar A, Zavadskas E, Streimikiene D (2020a) Measuring the impact of renewable energy, public health expenditure, logistics, and environmental performance on sustainable economic growth. Sustain Dev 28(4):833-843

Khan SAR, Zhang Y, Sarwat S, Godil DI, Amin S, Shujaat S (2021b) The role of block chain technology in circular economy practices to improve organisational performance. Int J Logist Res Appl. https://doi.org/10.1080/13675567.2021.1872512

Lai C-C, Shih T-P, Ko W-C, Tang H-J, Hsueh P-R (2020) Severe acute respiratory syndrome coronavirus 2 (SARS-CoV-2) and coronavirus disease-2019 (COVID-19): the epidemic and the challenges. Int J Antimicrob Agents 55:105924

Linardon J, Fuller-Tyszkiewicz M (2020) Attrition and adherence in smartphone-delivered interventions for mental health problems: A systematic and meta-analytic review. J Consult Clin Psychol $88: 1$

Menut L, Bessagnet B, Siour G et al (2020) Impact of lockdown measures to combat Covid-19 on air quality over western Europe. Sci Total Environ 140426

Manisalidis I, Stavropoulou E, Stavropoulos A, Bezirtzoglou E (2020) Environmental and health impacts of air pollution: a review. Front. Public Health 8:14

Martelletti L, Martelletti P (2020) Air pollution and the novel covid19 disease: a putative disease risk factor. SN compr. Clin Med Apr 15, 1-5

Muhammad S, Long X, Salman M (2020) COVID-19 pandemic and environmental pollution: a blessing in disguise? Sci Total Environ $138820 \mathrm{https}$ ://doi.org/10.1016/j.scitotenv.2020.138820

Naqvi H (2020) Economists warn of recession amid virus lockdowns. Retrieved from Profit https://profit.pakistantoday.com.pk/2020/ 03/30/economists-warn-of-recession-amid-virus-lockdowns/

Nation U (2020) Department of Economic and Social Affairs. Department of Economic and Social Affairs-UN

OPHI (2020) https://ophi.org.uk/global-mpi 2020

Pothirat C, Chaiwong W, Liwsrisakun C, Bumroongkit C, Deesomchok A, Theerakittikul T, Limsukon A, Tajarernmuang P, Phetsuk N (2019) Acute effects of air pollutants on daily mortality and hospitalizations due to cardiovascular and respiratory diseases. J Thorac Dis 11:3070-3083

Pata UK (2020) How is COVID-19 affecting environmental pollution in US cities? Evidence from Asymmetric Fourier Causality Test. Air Qual Atmos Heal 1-7

Persico C, Johnson KR (2020) The effects of increased pollution on COVID-19 cases and deaths. Available SSRN 3633446

Qiu YC (2020) Impacts of social and economic factors on the transmission of coronavirus disease (COVID-19) in China Retrieved from https://doi.org/10.1101/2020.03.13.20035238 
Reardon TB (2020) How COVID-19 may disrupt food supply chains in developing countries. IFPRI Research Post, 2 April 2020

Shahzad F, Shahzad U, Fareed Z et al (2020) Asymmetric nexus between temperature and COVID-19 in the top ten affected provinces of China: A current application of quantile-onquantile approach. Sci Total Environ 139115

Shrestha AM, Shrestha UB, Sharma R, Bhattarai S, Tran HNT, Rupakheti M (2020) Lockdown caused by COVID-19 pandemic reduces air pollution in cities worldwide. Environ. Pollut. (submitted paper)

Tobías A, Carnerero C, Reche C, Massagué J, Via M, Minguillón MC, Alastuey A, Querol X (2020) Changes in air quality during the lockdown in Barcelona (Spain) one month into the SARSCoV-2 epidemic. Sci Total Environ 726:138540. https://doi. org/10.1016/j.scitotenv.2020.138540

UNCTAD (2020) The Covid-19 shock to developing countries: Towards a "whatever it takes" programme for the two-thirds of the world's population being left behind. . United Nations Conference on Trade and Development

UNDP (2020a) Assessment report on impact of COVID-19 pandemic on Chinese enterprises. . United Nations Development Programme

UNDP (2020b) COVID-19: Looming crisis in developing countries threatens to devastate economies and ramp up inequality. United Nations Development Programme

Wang Q, Su M (2020) A preliminary assessment of the impact of COVID-19 on environment-a case study of China. Sci Total Environ 728:138915. https://doi.org/10.1016/j. scitotenv. 2020.138915

Wilson A, Reich BJ, Nolte CG, Spero TL, Hubbell B, Rappold AG (2017) Climate change impacts on projections of excess mortality at 2030 using spatially varying ozone-temperature risk surfaces. J Expo Sci Environ Epidemiol 27:118-124

Williams S (2013) Small and medium-sized enterprises and sustainability: Managers' values and engagement with environmental and climate change issues. Business Strategy and the Environment. 22(3):173-186

Yin Y, Wunderink RG (2018) MERS, SARS and other coronaviruses as causes of pneumonia. Respirology 23:130-137

Yongjian Z, Jingu X, Fengming H, Liqing C (2020) Association between short-term exposure to air pollution and COVID-19 infection: Evidence from China. Sci Total Environ 138704

Zambrano-Monserrate MA, Ruano MA, Sanchez-Alcalde L (2020) Indirect effects of COVID-19 on the environment Sci. Total Environ. 728 https://doi.org/10.1016/j.scitotenv.2020.138813

Zhang R, Zhang Y, Lin H, Feng X, Fu T-M, Wang Y (2020) NOx emission reduction and recovery during COVID-19 in east China. Atmosphere 11(4):433. https://doi.org/10.3390/atmos11040433

Zhang Y, Khan SAR, Kumar A, Golpîra H, Sharif A (2019) Is tourism really affected by logistical operations and environmental degradation? An empirical study from the perspective of Thailand. J Clean Prod 227:158-166

Zhang Y, Ma T, Khan SAR (2020) Investigating the effect of government subsidies on end-of-life vehicle recycling. Waste Manag Res September 2020. https://doi.org/10.1177/0734242X20953893

Zhu N, Zhang D, Wang W, Li X, Yang B, Song J, Lu R (2020) A novel coronavirus from patients with pneumonia in China, 2019. New England Journal of Medicine. https://doi.org/10.1056/ NEJMoa2001017

Zoran MA, Savastru RS, Savastru DM, Tautan MN (2020) Assessing the relationship between surface levels of PM2. 5 and PM10 particulate matter impact on COVID-19 in Milan, Italy. Sci Total Environ 139825

\section{Other references}

Avi Loeb AB (2020) Flattening the COVID-19 curves, [Internet]. Scientific american blog network, [cited 2020 July 30]. Available from: https://blogs.scientificamerican com/observations/ flattening-the-covid-19-curves/

AEMO (2020) COVID-19 demand impact in Australia. https://aemo.com. $\mathrm{au} / \mathrm{en} /$ news/demand-impact-australia-covid19. date accessed: 17 th July, 2020

Buck T, Arnold M, Chazan G, Cookson C (2020) Coronavirus declared a pandemic as fears of economic crisis mount, [Internet], [cited 2020 July 19]. Available from: https://www.ft.com/content/d72f1e546396-11ea-b3f3-fe4680ea68b5

Business Insider (2020) GmbH finanzen net, 'There is no escape': stocks, oil, and bitcoin plunge as US lawmakers fight over coronavirus rescue package Markets Insider, [Internet]. markets. businessinsider.com. [cited 2020 Aug 8]. Available from: https://markets.businessinsider.com/news/stocks/no-escapestocks-oil-bitcoin-plungesenate-argues-coronavirus-bill-2020-31029021850

BPF (2020) Plastics trade body publishes first study of coronavirus impact on UK manufacturing,[Internet]. [cited 2020 Aug 8]. Available from:https://www.bpf.co.uk/article/plastics-trade-bodypublishes-first-study-of-coronavirus-impact-1602.aspx

COVID-19 is coming for the chemical industry in 2020, BASF frets I IndustryWeek, [Internet]. [cited 2020 Aug 8]. Available from:https://www.industryweek.com/supply-chain/planningforecasting/article/21125045/covid19-is-coming-for-thechemicalindustry-in-2020-basf-frets

CPN (2020) (Coronavirus pandemic News Coronavirus): travel restrictions, border shutdowns by countryl Al Jazeera, [Internet]. [cited 2020 July 30]. Available from:https://www.aljazeera.com/ news/2020/03/coronavirus-travel-restrictionsborder-shutdownscountry-200318091505922.html

EIA (2020) https://www.eia.gov/todayinenergy/detail.php?id=43636. Date accessed: 27th June, 2020. 2020

GOV UK (2020) Guidance on social distancing for everyone in the UK, [Internet]. GOV.UK. [cited 2020 July 30]. Available from: https://www.gov.uk/government/publications/covid-19-guidanceon-social-distancing-and-for-vulnerable-people/guidanceonsocial-distancing-for

IATA (2020) https://www.iata.org/en/pressroom/pr/2020-06-09-01/

NASA (2020) NASA Science MARS 2020 Mission Perseverance Rover https://mars.nasa.gov/mars2020/ [Accessed on December 03, 2020]

NPR (2020) Oil prices, stocks plunge after Saudi Arabia stuns world with massive discounts, [Internet]. NPR.org. [cited 2020 Aug 8]. Available from:https://www.npr.org/2020/03/08/813439501/saudiarabia-stuns-world-with-massive-discount-in-oilsold- to-asiaeurope-and-u-

Picheta R (2020) was a terrible year. But the world's in better shape than you might think, https://edition.cnn.com/2020/12/25/europe/ 2020-improving-world-recap-scli-intl/index.html [Accessed on December 02, 2020]

Rajvikram M, Shafiullah GM, Kannadasan R, Mudgal V, Arif MT, Jamal $\mathrm{T}$ et al (2020) COVID-19: Impact Analysis and Recommendations for Power and Energy Sector Operation EnerarXiv-preprint.https:// www.researchgate.net/publication/341204513_COVID-19_Impact_ Analysis_and_Recommendations_for_Power_and_Energy_Sector_ Operation_EnerarXiv-preprint. Date accessed: 17th July, 2020

S\&P Global (2020) Japan, Singapore lockdowns to stifle Asian gas, power demand further. https://www.spglobal.com/platts/en/marketinsights/latest-news/natural-gas/040720-japan-singapore- 
lockdowns-to-stifle-asian-gas-power-demand-further. Date accessed: 17th June, 2020. 2020

UNDP (2020c) https://www.undp.org/content/undp/en/home/ coronavirus/socio-economic-impact-of-covid-19.html

Worldometer (2020) https://www.worldometers.info/coronavirus/ countries-where-coronavirus-has-spread/
WHO (2020) Rolling updates on coronavirus disease (COVID-19) at https://www.who.int/emergencies/diseases/novel-coronavirus-2019/ events-asthey-happen

Publisher's Note Springer Nature remains neutral with regard to jurisdictional claims in published maps and institutional affiliations. 